\title{
Land Inequality and the Origin of Divergence and Overtaking in the Growth Process: Theory and Evidence*
}

\author{
Oded Galor, Omer Moav and Dietrich Vollrath ${ }^{\dagger}$
}

February 7, 2003

\begin{abstract}
This research suggests that the distribution of land within and across countries affected the nature of the transition from an agrarian to an industrial economy generating diverging growth patterns across countries. Land abundance, which was beneficial in early stages of development, generated in later stages a hurdle for human capital accumulation and economic growth among countries in which land ownership was unequally distributed. The qualitative change in the role of land in the process of industrialization affected the transition to modern growth and has brought about changes in the ranking of countries in the world income distribution. Some land abundant countries that were associated with the club of the rich economies in the pre-industrial revolution era and were marked by an unequal distribution of land, were overtaken in the process of industrialization by land scarce countries and were dominated by other land abundant economies in which land distribution was rather equal. The theory focuses on the economic incentives that led landowners to resist growth enhancing educational expenditure. The basic premise of this research, regarding the negative effect of land inequality on public expenditure on education is supported empirically based on cross-state data from the High School Movement in the first half of the 20th century in the US.
\end{abstract}

Keywords: Land Inequality, development, human capital accumulation, growth JEL classification Numbers: O10, O40,

*We thank Josh Angrist, Andrew Foster, Eric Gould, Vernon Henderson, Saul Lach, Victor Lavy, Daniele Paserman, and David Weil for helpful discussions and seminar participants at Brown University, Tel-Aviv University, the NBER Summer Institute, 2002, and the Economics of Water and Agriculture, 2002, for helpful comments. Galor's research is supported by NSF Grant SES-0004304.

${ }^{\dagger}$ Galor: Hebrew University and Brown University; Moav: Hebrew University; Vollrath: Brown University. 


\section{Introduction}

This research suggests that the distribution of land within and across countries affected the nature of the transition from an agrarian to an industrial economy, generating diverging growth patterns across countries. Land abundance, which was beneficial in early stages of development, brought about a hurdle for human capital accumulation and economic growth among countries that were marked by an unequal distribution of land ownership. The qualitative change in the role of land in the process of industrialization has brought about changes in the ranking of countries in the world income distribution. Some land abundant countries which were associated with the club of the rich economies in the pre-industrial revolution era and were characterized by an unequal distribution of land, were overtaken in the process of industrialization by land scarce countries and were dominated by other land abundant economies in which land distribution was rather equal.

The accumulation of physical capital in the process of industrialization has raised the importance of human capital in the growth process, reflecting the high degree of complementarity between capital and skills. Investment in human capital, however, has been sub-optimal due to credit markets imperfections, and public investment in education has been growth enhancing. Nevertheless, human capital accumulation has not benefited all sectors of the economy. Due to a low degree of complementarity between human capital and land, ${ }^{1}$ universal public education has increased the cost of labor beyond the increase in average labor productivity in the agricultural sector, reducing the return to land. Landowners, therefore, had no economic incentives to support these growth enhancing educational policies as long as their stake in the productivity of the industrial

\footnotetext{
${ }^{1}$ Although, rapid technological change in the agricultural sector may increase the return to human capital (e.g., Foster and Rosenzweig (1996) in the context of the Green Revolution in India), the return to education is typically lower in the agricultural sector, as evident by the distribution of employment in the agricultural sector. For instance, as reported by the U.S. department of Agriculture (1998), 56.9\% of agricultural employment consists of high school dropouts, in contrast to an average of $13.7 \%$ in the economy as a whole. Furthermore, $16.6 \%$ of agricultural employment consists of workers with 13 or more years of schooling, in contrast to an average of $54.5 \%$ in the economy as a whole.
} 
sector was insufficient. ${ }^{2}$

The adverse effect of the implementation of universal public education on landowners' income from agricultural production is magnified by the degree of concentration of land ownership. The theory suggests therefore that as long as landowners have affected the political process and thereby the implementation of education reforms, inequality in the distribution of land ownership has been a hurdle for human capital accumulation and has thereby impeded the process of industrialization and the transition to modern growth. ${ }^{3}$ In these economies an inefficient education policy persisted and the growth path was retarded. ${ }^{4}$ In contrast, in societies in which agricultural land was scarce or land ownership was distributed rather equally, growth enhancing education policies were implemented. ${ }^{5}$ The process of industrialization fueled by the accumulation of physical capital, has raised the interest of landowners in the productivity of the industrial sector and might have brought about a qualitative change in landowners' attitudes towards education reforms. In particular, among land abundant economies, those in which land is equally distributed adopted growth-enhancing public education earlier, generating diverging growth patterns across countries. ${ }^{6}$

\footnotetext{
${ }^{2}$ Landowners may benefit from the economic development of other segments of the economy due to: capital ownership, household's labor supply to the industrial sector, extraction, taxation, the provision of public goods, and demand spillover from economic development of the urban sector.

${ }^{3}$ Consistently with the proposed theory, Deininger and Squire (1998) document that the level of education and economic growth over the period 1960-1992 are inversely related to land inequality (across landowners) and the relationship is more pronounced in developing countries.

${ }^{4}$ In contrast to the political economy mechanism proposed by Persson and Tabellini (2000), where land concentration induces landowners to divert resources in their favor via distortionary taxation, in the proposed theory land concentration induces lower taxation so as to assure lower public expenditure on education, resulting in a lower economic growth. The proposed theory is therefore consistent with empirical findings that taxation is positively related to economic growth (e.g., Perotti (1996)).

${ }^{5}$ The potentially adverse relationship between natural resources and growth is evident even in smaller time frames. Sachs and Warner (1995) and Gylfason (2001) document a significant inverse relationship between natural resources and growth in the post World-War II era. Gylfason finds that a 10\% increase in the amount of natural capital is associated with a fall of about $1 \%$ in the growth rate. Furthermore, Gylfason (2001) argues that natural resources crowd out human capital. In a cross section study, he reports significant negative relationships between the share of natural capital in national wealth and public spending on education, expected years of schooling, and secondary-school enrollments.

${ }^{6}$ According to the theory, therefore, land reform would bring about an increase in the investment in human capital. The differential increase in the productivity of workers in the industrial and the agricultural sectors would generate migration from the agricultural to the industrial sector accompanied
} 
The predictions of the theory regarding the adverse effect of the concentration of land ownership on the implementation of education reforms is examined empirically based on cross-state data from the High School Movement in the first half of the 20th century in the US. Variations in public spending on education across states in the US during the high school movement are utilized in order to examine the thesis that land inequality was a hurdle for public investment in human capital. Historical evidence from the US on education expenditures and land ownership in the period 1880-1950 suggests that land inequality had a significant adverse effect on the timing of educational reforms during the high school movement in the United States.

In addition, anecdotal evidence suggests that indeed the distribution of land within and across countries affected the nature of the transition from an agrarian to an industrial economy and has been significant in the emergence of sustained differences in human capital, income levels, and growth patterns across countries. ${ }^{7}$ The link between land reforms and the increase in governmental investment in education that is apparent in the process of development of several countries lends credence to the proposed theory.

The process of development in Korea was marked by a major land reform that was followed by a massive increase in governmental expenditure on education. During the Japanese occupation in the period 1905-1945, land distribution in Korea became increasingly skewed and in 1945 nearly $70 \%$ of Korean farming households were simply tenants [Eckert, 1990]. In 1949, the Republic of Korea instituted the Agricultural Land Reform Amendment Act that drastically affected landholdings. Individuals could only own land if they cultivated or managed it themselves, they could own a maximum of three hectares, and land renting was prohibited. This land reform had dramatic effect on landownership. Owner cultivated farm households increased from 349,000 in 1949 to $1,812,000$ in 1950, and tenant farm households declined from 1,133,000 in 1949 to nearly zero in 1950. [Yoong, 2000]. Consistent with the proposed theory, following the by an increase in agricultural wages and a decline in agricultural employment. Consistent with the proposed theory, Besley and Burgess (2000) find that over the period 1958-1992 in India, land reforms have raised agricultural wages, despite an adverse effect on agricultural output.

${ }^{7}$ See Gerber (1991), Colleman and Caselli (2001) and Bertocchi (2002) as well. 
decline in the inequality in the distribution of land, expenditure on education soared. In 1948, Korea allocated $8 \%$ of government expenditures to education. Following a slight decline due to the Korean war, educational expenditure in South Korea has increased to $9.2 \%$ in 1957 and $14.9 \%$ in 1960 , remaining at about $15 \%$ thereafter. Land reforms and the subsequent increase in governmental investment in education were followed by a stunning growth performance that permitted Korea to nearly triple its income relative to the United States in about twenty years, from $9 \%$ in 1965 to $25 \%$ in 1985 . Hence, consistently with the proposed theory, prior to its land reforms Korea's income level was well below that of land-abundant countries in North and South America. However, in the aftermath of the Korean's land reform and its apparent effect on human capital accumulation, Korea overtook some land abundant countries in South America that were characterized by unequal distribution of land (Table 1).

North and South America provide anecdotal evidence for differences in the process of development, and possibly overtaking, due to the effects of the distribution of land ownership on education reforms within land-abundant economies. As argued by Sokoloff (2000) the original colonies in North and South America had vast amounts of land per person and income levels comparable to the European ones. North and Latin America differed in the distribution of land and resources. The United States and Canada were deviant cases in their relatively egalitarian distribution of land. For the rest of the new world, land and resources were concentrated in the hand of a very few, and this concentration persisted over a very long period [Sokoloff, 2000]. ${ }^{8}$ Consistent with the proposed theory, these differences in land distribution between North and Latin America, were associated with significant differences in investment in human capital. As argued by Coatsworth (1993 pp 26-7) in the US there was a widespread property ownership, early public commitment to educational spending, and a lesser degree of concentration of wealth and income whereas in Latin America public investment in human capital remained well below the levels achieved at comparable levels of national income in more

\footnotetext{
${ }^{8}$ For instance, in Mexico in 1910, $0.2 \%$ of the active rural population owned $87 \%$ of the land [Estevo, 1983].
} 
developed countries. ${ }^{9}$ Furthermore, Sokoloff (2000) maintains that although all of the economies in the western hemisphere were rich enough in the early 19th century to have established primary schools, only the United States and Canada made the investments necessary to educate the general population. The proposed theory suggests that the divergence in the growth performance of North and Latin America in the second half of the twentieth century, as documented in Table 1 (e.g., Argentina, Brazil, Chile and Mexico vs. the US and Canada), may be attributed in part to the more equal distribution of land in the North, whereas the overtaking (e.g., Mexico and Columbia overtaken by Korea and Taiwan) may be attributed to the positive effect of land abundance in early stages of development and its adverse effect in later stages of development.

The disparity in income per capita across countries has markedly increased in the last two centuries and reversals of relative income levels have been documented [Maddison, 2001, Acemoglu et al. 2002]. Divergence and overtaking, was attributed to initial differences in effective resources [Galor and Weil, 2000], geography [Diamond 1997, and Sacks and Werner 1995] institutions [North, 1981, Engerman and Sokoloff, 1997, Acemoglu et al. 2002], asymmetrical effects of international trade [Galor and Mountford, 2001], and the voracity effect [Lane and Tornel, 1996]. ${ }^{10}$

In contrast, the proposed theory suggests that in economies marked by an unequal distribution of land ownership, land abundance that was a source of richness in early stages of development, is in fact the factor that led in later stages to under-investment in human capital and slower economic growth. In unequal societies, land and resource abundance, which made nations prosperous in the eve industrialization, had generated economic incentives for their owners that stifle economic growth over a long lasting period.

\footnotetext{
${ }^{9}$ As argued by Sokolof (2000), even among Latin American countries variations in the degree of inequality in the distribution of land ownership were reflected in variation in investment in human capital. In particular, Argentina, Chile and Uruguay in which land inequality was less pronounces invested significantly more in education.

${ }^{10}$ See Roderigues and Sachs (1999) as well.
} 


\section{The Basic Structure of the Model}

Consider an overlapping-generations economy in a process of development. In every period the economy produces a single homogeneous good that can be used for consumption and investment. The good is produced in an agricultural sector and in a manufacturing sector using land, physical and human capital as well as raw labor. The stock of physical capital in every period is the output produced in the preceding period net of consumption and human capital investment, whereas the stock of human capital in every period is determined by the aggregate public investment in education in the preceding period. The supply of land is fixed over time and output grows due to the accumulation of physical and human capital.

\subsection{Production of Final Output}

The output in the economy in period $t, y_{t}$, is given by the aggregate output in the agricultural sector, $y_{t}^{A}$, and in the manufacturing sector, $y_{t}^{M}$;

$$
y_{t}=y_{t}^{A}+y_{t}^{M} \text {. }
$$

\subsubsection{The Agricultural Sector}

Production in the agricultural sector occurs within a period according to a neoclassical, constant-returns-to-scale production technology, using labor and land as inputs. The output produced at time $t, y_{t}^{A}$, is

$$
y_{t}^{A}=F\left(X_{t}, L_{t}\right)
$$

where $X_{t}$ and $L_{t}$ are land and the number of workers, respectively, employed by the agricultural sector in period $t$. Hence, workers' productivity in the agricultural sector is independent of their level of human capital. The production function is strictly increasing

and concave, the two factors are complements in the production process, $F_{X L}>0$, and the function satisfies the neoclassical boundary conditions that assure the existence of 
an interior solution to the producers' profit-maximization problem. ${ }^{11}$

Producers in the agricultural sector operate in a perfectly competitive environment. Given the wage rate per worker, $w_{t}^{A}$, and the rate of return to land, $\rho_{t}$, producers in period $t$ choose the level of employment of labor, $L_{t}$, and land, $X_{t}$, so as to maximize profits. That is, $\left\{X_{t}, L_{t}\right\}=\arg \max \left[F\left(X_{t}, L_{t}\right)-w_{t} L_{t}-\rho_{t} X_{t}\right]$. The producers' inverse demand for factors of production is therefore,

$$
\begin{gathered}
w_{t}^{A}=F_{L}\left(X_{t}, L_{t}\right) ; \\
\rho_{t}=F_{X}\left(X_{t}, L_{t}\right) .
\end{gathered}
$$

\subsubsection{Manufacturing Sector}

Production in the manufacturing sector occurs within a period according to a neoclassical, constant-returns-to-scale, Cobb-Douglas production technology using physical and human capital as inputs. The output produced at time $t, y_{t}^{M}$, is

$$
y_{t}^{M}=K_{t}^{\alpha} H_{t}^{1-\alpha}=H_{t} k_{t}^{\alpha} ; \quad k_{t} \equiv K_{t} / H_{t} ; \quad \alpha \in(0,1)
$$

where $K_{t}$ and $H_{t}$ are the quantities of physical capital and human capital (measured in efficiency units) employed in production at time $t$. Both factors depreciate fully after one period. In contrast to the agricultural sector, human capital has a positive effect on workers' productivity in the manufacturing sector, increasing workers' efficiency units of labor.

Producers in the manufacturing sector operate in a perfectly competitive environment. Given the wage rate per efficiency unit of human capital, $w_{t}^{M}$, and the rate of return to capital, $R_{t}$, producers in period $t$ choose the level of employment of capital, $K_{t}$, and the number of efficiency units of human capital, $H_{t}$, so as to maximize profits. That is, $\left\{K_{t}, H_{t}\right\}=\arg \max \left[K_{t}^{\alpha} H_{t}^{1-\alpha}-w_{t}^{M} H_{t}-R_{t} K_{t}\right]$. The producers' inverse demand

\footnotetext{
${ }^{11}$ The abstraction from technological change is merely a simplifying assumption. The introduction of endogenous technological change would allow output in the agricultural sector to increase over time despite the decline in the number of workers in this sector.
} 
for factors of production is therefore

$$
\begin{aligned}
& R_{t}=\alpha k_{t}^{\alpha-1} \equiv R\left(k_{t}\right) \\
& w_{t}^{M}=(1-\alpha) k_{t}^{\alpha} \equiv w^{M}\left(k_{t}\right) .
\end{aligned}
$$

\subsection{Individuals}

In every period a generation which consists of a continuum of individuals of measure 1 is born. Individuals live for two periods. Each individual has a single parent and a single child. Individuals, within as well as across generations, are identical in their preferences and innate abilities but they may differ in their wealth.

Preferences of individual $i$ who is born in period $t$ (a member $i$ of generation $t$ ) are

defined over second period consumption, ${ }^{12} c_{t+1}^{i}$, and a transfer to the offspring, $b_{t+1}^{i} \cdot{ }^{13}$ They are represented by a log-linear utility function

$$
u_{t}^{i}=(1-\beta) \log c_{t+1}^{i}+\beta \log b_{t+1}^{i},
$$

where $\beta \in(0,1)$.

In the first period of their lives individuals devote their entire time for the acquisition of human capital. In the second period of their lives individuals join the labor force, allocating the resulting wage income, along with their return to capital and land, between consumption and income transfer to their children. In addition, individuals transfer their entire stock of land to their offspring.

An individual $i$ born in period $t$ receives a transfer, $b_{t}^{i}$, in the first period of life. A fraction $\tau_{t} \geq 0$ of this capital transfer is collected by the government in order to finance public education, whereas a fraction $1-\tau_{t}$ is saved for future income. Individuals devote their first period for the acquisition of human capital. Education is provided publicly free of charge. The acquired level of human capital increases with the real resources invested

\footnotetext{
${ }^{12}$ For simplicity we abstract from first period consumption. It may be viewed as part of the consumption of the parent.

${ }^{13}$ This form of altruistic bequest motive (i.e., the "joy of giving") is the common form in the recent literature on income distribution and growth. It is supported empirically by Altonji, Hayashi and Kotlikoff (1997).
} 
in public education. The number of efficiency units of human capital of each member of generation $t$ in period $t+1, h_{t+1}$, is a strictly increasing, strictly concave function of the government real expenditure on education per member of generation $t, e_{t}{ }^{14}$

$$
h_{t+1}=h\left(e_{t}\right)
$$

where $h(0)=1, \lim _{e_{t} \rightarrow 0^{+}} h^{\prime}\left(e_{t}\right)=\infty$, and $\lim _{e_{t} \rightarrow \infty} h^{\prime}\left(e_{t}\right)=0$. Hence, even in the absence of real expenditure on public education individuals posses one efficiency unit of human capital - basic skills.

In the second period life, members of generation $t$ join the labor force earning the competitive market wage $w_{t+1}$. In addition, individual $i$ derives income from capital ownership, $b_{t}^{i}\left(1-\tau_{t}\right) R_{t+1}$, and from the return on land ownership, $x^{i} \rho_{t+1}$, where $x^{i}$ is the quantity of land owned by individual $i$. The individual's second period income, $I_{t+1}^{i}$, is therefore

$$
I_{t+1}^{i}=w_{t+1}+b_{t}^{i}\left(1-\tau_{t}\right) R_{t+1}+x^{i} \rho_{t+1}
$$

A member $i$ of generation $t$ allocates second period income between consumption, $c_{t+1}^{i}$, and transfers to the offspring, $b_{t+1}^{i}$, so as to maximize utility subject to the second period budget constraint

$$
c_{t+1}^{i}+b_{t+1}^{i} \leq I_{t+1}^{i}
$$

Hence the optimal transfer of a member $i$ of generation $t$ is, ${ }^{15}$

$$
b_{t+1}^{i}=\beta I_{t+1}^{i}
$$

The indirect utility function of a member $i$ of generation $t, v_{t}^{i}$ is therefore

$$
v_{t}^{i}=\log I_{t+1}^{i}+\xi \equiv v\left(I_{t+1}^{i}\right),
$$

\footnotetext{
${ }^{14} \mathrm{~A}$ more realistic formulation would link the cost of education to (teacher's) wages, which may vary in the process of development. As can be derived from section 2.4, under both formulations the optimal expenditure on education, $e_{t}$, is an increasing function of the capital-labor ratio in the economy, and the qualitative results remain therefore intact.

${ }^{15}$ Note that individual's preferences defined over the transfer to the offspring, $b_{t}^{i}$, or over net transfer, $\left(1-\tau_{t}\right) b_{t}^{i}$, are represented in an indistinguishable manner by the log linear utility function. Under both definitions of preferences the bequest function is given by $b_{t+1}^{i}=\beta I_{t+1}^{i}$.
} 
where $\xi \equiv(1-\beta) \log (1-\beta)+\beta \log \beta$. The indirect utility function is monotonically increasing in $I_{t+1}^{i}$.

\subsection{Physical Capital, Human Capital, and Output}

Let $B_{t}$ denote the aggregate level of intergenerational transfers in period $t$. It follows from (8) and (10) that,

$$
B_{t}=\beta y_{t}
$$

A fraction $\tau_{t}$ of this capital transfer is collected by the government in order to finance public education, whereas a fraction $1-\tau_{t}$ is saved for future consumption. The capital stock in period $t+1, K_{t+1}$, is therefore

$$
K_{t+1}=\left(1-\tau_{t}\right) \beta y_{t}
$$

whereas the government tax revenues are $\tau_{t} \beta y_{t}$.

Since population is normalized to 1 , the education expenditure per young individual in period $t, e_{t}$, is,

$$
e_{t}=\tau_{t} \beta y_{t}
$$

and the stock of human capital, employed in the manufacturing sector in period $t+1$, $H_{t+1}$, is therefore,

$$
H_{t+1}=\theta_{t+1} h\left(\tau_{t} \beta y_{t}\right),
$$

where, $\theta_{t+1}$ is the fraction (and the number) of workers employed in the manufacturing sector. Hence, output in the manufacturing sector in period $t+1$ is,

$$
y_{t+1}^{M}=\left[\left(1-\tau_{t}\right) \beta y_{t}\right]^{\alpha}\left[\theta_{t+1} h\left(\tau_{t} \beta y_{t}\right)\right]^{1-\alpha} \equiv y^{M}\left(y_{t}, \tau_{t}, \theta_{t+1}\right)
$$

and the physical-human capital ratio $k_{t+1} \equiv K_{t+1} / H_{t+1}$ is,

$$
k_{t+1}=\frac{\left(1-\tau_{t}\right) \beta y_{t}}{\theta_{t+1} h\left(\tau_{t} \beta y_{t}\right)} \equiv k\left(y_{t}, \tau_{t}, \theta_{t+1}\right),
$$

where $k_{t+1}$ is strictly decreasing in $\tau_{t}$ and in $\theta_{t+1}$, and strictly increasing in $y_{t}$. As follows from (5), the capital share in the manufacturing sector is

$$
\left(1-\tau_{t}\right) \beta y_{t} R_{t+1}=\alpha y_{t+1}^{M}
$$


and the labor share in the manufacturing sector is given by

$$
\theta_{t+1} h\left(\tau_{t} \beta y_{t}\right) w_{t+1}^{M}=(1-\alpha) y_{t+1}^{M}
$$

The supply of labor to agriculture, $L_{t+1}$, is equal to $1-\theta_{t+1}$. Output in the agriculture sector in period $t+1$ is therefore

$$
y_{t+1}^{A}=F\left(X, 1-\theta_{t+1}\right) \equiv y^{A}\left(\theta_{t+1} ; X\right)
$$

As follows from the properties of the production functions as long as, $X>0$, and $\tau_{t}<1$, noting that $y_{t}>0$ for all $t$, both sectors are active in $t+1$. Hence, since individuals can either supply one unit of labor to the agriculture sector and receive the wage $w_{t+1}^{A}$ or supply $h_{t+1}$ units of human capital to the manufacturing sector and receive the wage income $h_{t+1} w_{t+1}^{M}$ it follows that

$$
w_{t+1}^{A}=h_{t+1} w_{t+1}^{M} \equiv w_{t+1},
$$

and the division of labor between the two sectors, $\theta_{t+1}$, noting $(3),(5)$ and (17) is determined accordingly.

Since the number of individuals in each generation is normalized to 1, aggregate wage income in the economy, which equals to the sum of labor shares in the two sectors, equals $w_{t+1}$. Namely, as follows from (3), (19) and (20),

$$
w_{t+1}=\left(1-\theta_{t+1}\right) F_{L}\left(X, 1-\theta_{t+1}\right)+(1-\alpha) y_{t+1}^{M}
$$

Lemma 1 The fraction of workers employed by the manufacturing sector in period $t+1$, $\theta_{t+1}:$

(a) is uniquely determined:

$$
\theta_{t+1}=\theta\left(y_{t}, \tau_{t} ; X\right)
$$

where $\theta_{X}\left(y_{t}, \tau_{t} ; X\right)<0, \theta_{y}\left(y_{t}, \tau_{t} ; X\right)>0$, and $\lim _{y \rightarrow \infty} \theta\left(y_{t}, \tau_{t} ; X\right)=1$.

(b) maximizes the aggregate wage income, $w_{t+1}$, and output $y_{t+1}$ in period $t+1$ :

$$
\theta_{t+1}=\arg \max w_{t+1}=\arg \max y_{t+1}
$$




\section{Proof.}

(a) Substitution (3), (5), and (17) into (21) it follows that

$$
F_{L}\left(X, 1-\theta_{t+1}\right)=h\left(\tau_{t} \beta y_{t}\right)(1-\alpha)\left(\frac{\left(1-\tau_{t}\right) \beta y_{t}}{\theta_{t+1} h\left(\tau_{t} \beta y_{t}\right)}\right)^{\alpha}
$$

and therefore the Lemma follows from the properties of the agriculture production technology, $F\left(X, L_{t}\right)$, and the concavity of $h\left(e_{t}\right)$.

(b) Since $\theta_{t+1}$ equalizes the marginal return to labor in the two sectors, and since the marginal product of factors is decreasing in both sectors, part (b) follows.

Corollary 1 Given land size, $X$, prices in period $t+1$ are uniquely determined by $y_{t}$ and $\tau_{t}$. That is

$$
\begin{aligned}
w_{t+1} & =w\left(y_{t}, \tau_{t}\right) ; \\
R_{t+1} & =R\left(y_{t}, \tau_{t}\right) ; \\
\rho_{t+1} & =\rho\left(y_{t}, \tau_{t}\right) .
\end{aligned}
$$

Proof. Follows from (3), (5), (17), (20) and Lemma 1.

\subsection{Efficient Expenditure on Public Education}

This section demonstrates that the level of expenditure on public schooling (and hence the level of taxation) that maximizes aggregate output is optimal from the viewpoint of all individuals except for landowners who own a large fraction of the land in the economy.

Lemma 2 Let $\tau_{t}^{*}$ be the tax rate in period $t$, that maximizes aggregate output in period $t+1$

$$
\tau_{t}^{*} \equiv \arg \max y_{t+1}
$$

(a) $\tau_{t}^{*}$ equates the marginal return to physical capital and human capital:

$$
\theta_{t+1} w^{M}\left(k_{t+1}\right) h^{\prime}\left(\tau_{t}^{*} \beta y_{t}\right)=R\left(k_{t+1}\right) .
$$

(b) $\tau_{t}^{*}=\tau^{*}\left(y_{t}\right) \in(0,1)$ and $\tau^{*}\left(y_{t}\right) y_{t}$, is strictly increasing in $y_{t}$.

(c) $\tau_{t}^{*}=\arg \max w_{t+1}$ and $d w_{t+1} / d \tau_{t}>0$ for $\tau_{t} \in\left(0, \tau_{t}^{*}\right)$.

(d) $\tau_{t}^{*}=\arg \min \rho_{t+1}$ and $d \rho_{t+1} / d \tau_{t}<0$ for $\tau_{t} \in\left(0, \tau_{t}^{*}\right)$. 
(e) $\tau_{t}^{*}=\arg \max \theta\left(y_{t}, \tau_{t} ; X\right)$ and $d \theta\left(y_{t}, \tau_{t} ; X\right) / d \tau_{t}>0$ for $\tau_{t} \in\left(0, \tau_{t}^{*}\right)$.

(f) $\tau_{t}^{*}=\arg \max y_{t+1}^{M}$ and $d y_{t+1}^{M} / d \tau_{t}>0$ for $\tau_{t} \in\left(0, \tau_{t}^{*}\right)$.

(g) $\tau_{t}^{*}=\arg \max \left(1-\tau_{t}\right) R_{t+1}$ and $d\left(1-\tau_{t}\right) R_{t+1} / d \tau_{t}>0$ for $\tau_{t} \in\left(0, \tau_{t}^{*}\right)$.

\section{Proof.}

(a) As follows from (16) and (20) aggregate output in period $t+1, y_{t+1}$ is

$$
y_{t+1}=y^{M}\left(y_{t}, \tau_{t}, \theta_{t+1}\right)+y^{A}\left(\theta_{t+1} ; X\right) .
$$

Hence, since $\tau_{t}^{*}=\arg \max y_{t+1}$ and since, as established in Lemma 1, $\theta_{t+1}=\arg \max y_{t+1}$, it follows form the envelop theorem that the value of $\tau_{t}^{*}$ satisfies the condition in part (a).

(b) It follows from part (a), (5) and (17) that

$$
\frac{\left(1-\tau_{t}^{*}\right) \beta y_{t}}{h\left(\tau_{t}^{*} \beta y_{t}\right)}=\frac{\alpha}{(1-\alpha) h^{\prime}\left(\tau_{t}^{*} \beta y_{t}\right)}
$$

Hence, $\tau_{t}^{*}=\tau^{*}\left(y_{t}\right)<1$ and $\tau_{t}^{*}>0$ for all $y_{t}>0\left(\right.$ since $\left.\lim _{e_{t} \rightarrow 0^{+}} h^{\prime}\left(e_{t}\right)=\infty\right)$ and $\tau^{*}\left(y_{t}\right) y_{t}$ is strictly increasing in $y_{t}$.

(c) Follows from the differentiation of $w_{t+1}$ in (22) with respect to $\tau_{t}$ using the envelop theorem since, as established in Lemma $1, \theta_{t+1}=\arg \max w_{t+1}$.

(d) Follows from part (c) noting that along the factor price frontier $\rho_{t}$ decreases in $w_{t}^{A}$ and therefore in $w_{t}$.

(e) Follows from part (c) noting that, as follows from the properties of the production function (2), $L_{t+1}$ and $w_{t+1}^{A}$ are inversely related and hence $\theta_{t+1}=1-L_{t+1}$ is positively related to $w_{t+1}^{A}$ and therefore to $w_{t+1}$.

(f) Follows from differentiating $y_{t+1}^{M}$ in (16) with respect to $\tau_{t}$ noting that $y_{t+1}^{M}$ is strictly increasing in $\theta_{t+1}$ and as follows from part (e) $d \theta\left(X, y_{t}, \tau_{t}\right) / d \tau_{t}>0$ for $\tau_{t} \in\left(0, \tau^{*}\right)$.

(g) Follows from part (f) noting that, as follows from (18), $\left(1-\tau_{t}\right) R_{t+1}=\alpha y_{t+1}^{M} /\left(\beta y_{t}\right)$.

The size of the land, $X$, has two opposing effects on $\tau_{t}^{*}$. Since a larger land size implies that employment in the manufacturing sector is lower, the fraction of the labor force whose productivity is improved due to taxation that is designed to finance universal 
public education is lower. In contrast, the return to each unit of human capital employed in the manufacturing sector is higher while the return to physical capital is lower, since human capital in the manufacturing sector is scarce. Due to the Cobb-Douglass production function in the manufacturing sector the two effects cancel one another and as established in Lemma 2 the value of $\tau_{t}^{*}$ is independent of the size of land.

Furthermore, since the tax rate is linear and the elasticity of substitution between human and physical capital in the manufacturing sector is unitary, as established in Lemma 2, the tax rate that maximizes aggregate output in period $t+1$ also maximizes the wage per worker, $w_{t+1}$, and the net return to capital, $\left(1-\tau_{t}^{*}\right) R_{t+1}$. If the elasticity of substitution would be larger than unity but finite, then the tax rate that maximizes the wage per worker would have been larger than the optimal tax rate and the tax rate that maximizes the return to capital would have been lower, yet strictly positive. If the elasticity of substitution is smaller than unity, the opposite holds.

Corollary 2 The optimal level of taxation from the viewpoint of individual $i$, is $\tau_{t}^{*}$ for a sufficiently low $x^{i}$.

Proof. Since the indirect utility function, (11), is a strictly increasing function of the individual's second period wealth, and since as established in Lemma $2, w_{t+1}$, and $\left(1-\tau_{t}\right) R_{t+1}$ are maximized by $\tau_{t}^{*}$, it follows from (8) that, for a sufficiently low $x^{i}$, $\tau_{t}^{*}=\arg \max v\left(I_{t+1}^{i}\right)$.

Hence, the optimal level of taxation for individuals whose land ownership is sufficiently low equals the level of taxation (and hence the level of expenditure on public schooling) that maximizes aggregate output.

\subsection{Political Mechanism}

Suppose that changes in the existing educational policy require the consent of all segments of society. In the absence of consensus the existing educational policy remains intact. 
Suppose that consistently with the historical experience, societies initially do not finance education (i.e., $\tau_{0}=0$ ). It follows that unless all segments of society would find it beneficial to alter the existing educational policy the tax rate will remain zero. Once all segments of society find it beneficial to implement educational policy that maximizes aggregate output, this policy would remain in effect unless all segment of society would support an alternative policy.

\subsection{Landlords' Desirable Schooling Policy}

Suppose that in period 0 a fraction $\lambda \in(0,1)$ of all young individuals in society are Landlords while a fraction $1-\lambda$ are landless. Each landlord owns an equal fraction, $1 / \lambda$, of the entire stock of land, $X$, and is endowed with $b_{0}^{L}$ units of output. Since landlord are homogeneous in period 0 and since land is bequeathed from parent to child and each individual has a single child and a single parent, it follows that the distribution of land ownership in society and the division of capital within the class of landlord is constant over time, where each landlord owns $X / \lambda$ units of land and $b_{t}^{L}$ units of output in period $t$.

The income of each landlord in the second period of life, $I_{t+1}^{L}$, as follows from (8) and Corollary 1 is therefore

$$
I_{t+1}^{L}=w\left(y_{t}, \tau_{t}\right)+\left(1-\tau_{t}\right) R\left(y_{t}, \tau_{t}\right) b_{t}^{L}+\rho\left(y_{t}, \tau_{t}\right) X / \lambda,
$$

and $b_{t+1}^{L}$, as follows from (10) is therefore

$$
b_{t+1}^{L}=\beta\left[w\left(y_{t}, \tau_{t}\right)+\left(1-\tau_{t}\right) R\left(y_{t}, \tau_{t}\right) b_{t}^{L}+\rho\left(y_{t}, \tau_{t}\right) X / \lambda\right] \equiv b^{L}\left(y_{t}, b_{t}^{L}, \tau_{t} ; X / \lambda\right)
$$

Proposition 1 For any given level of capital and land ownership of each landlord $\left(b_{t}^{L}, \lambda ; X\right)$ there exists a sufficiently high level of output $\widehat{y}_{t}=\widehat{y}\left(b_{t}^{L}, \lambda ; X\right)$ above which the optimal taxation from a Landlord's viewpoint, $\tau_{t}^{L}$, maximizes aggregate output, i.e.,

$$
\tau_{t}^{L} \equiv \arg \max I_{t+1}^{L}=\tau_{t}^{*} \quad \text { for } y_{t} \geq \widehat{y}_{t}
$$

where $\widehat{y}\left(b_{t}^{L}, 1 ; X\right)=0 ; \lim _{\lambda \rightarrow 0} \widehat{y}\left(b_{t}^{L}, \lambda ; X\right)=\infty$; 
$\widehat{y}_{\lambda}\left(b_{t}^{L}, \lambda ; X\right)<0 ; \widehat{y}_{X}\left(b_{t}^{L}, \lambda ; X\right)>0$.

Proof. Follows from the properties of the agriculture production function (2), Lemma 1 and 2 , noting that, since $1-\theta_{t+1}=\arg \max \rho_{t+1}$, for $b_{t}^{L}=0, d I_{t+1}^{L} / d w_{t+1}>0$ if $\lambda>1-\theta_{t+1}$.

Corollary 3 For any given level of capital and land ownership of each landlord $\left(b_{t}^{L}, \lambda ; X\right)$ there exists a sufficiently high level of output $\widehat{y}_{t}=\widehat{y}\left(b_{t}^{L}, \lambda ; X\right)$ above which the level of taxation, $\tau_{t}^{*}$, that maximizes aggregate output, is optimal from the viewpoint of every member of society.

Lemma 3 (a) The equilibrium tax rate in period $t, \tau_{t}$, is equal to either 0 or $\tau_{t}^{*}$, i.e.,

$$
\tau_{t} \in\left\{0, \tau_{t}^{*}\right\}
$$

(b) If $\hat{t}$ is the first period in which $\tau_{t}=\tau_{t}^{*}$ then

$$
\tau_{t}=\tau_{t}^{*} \quad \forall t \geq \hat{t} .
$$

Proof. follows from the political structure, Corollary 2 and the assumption that $\tau_{0}=0$.

Lemma 4 Landlords desirable tax rate in period $t, \tau_{t}^{L}$,

$$
\tau_{t}^{L}=\left\{\begin{array}{ccc}
\tau_{t}^{*} & \text { if } \quad b_{t}^{L} \geq \hat{b}_{t} \\
0 & \text { if } \quad b_{t}^{L}<\hat{b}_{t}
\end{array}\right.
$$

where

$$
\hat{b}_{t}=\frac{w\left(y_{t}, 0\right)-w\left(y_{t}, \tau_{t}^{*}\right)+\left[\rho\left(y_{t}, 0\right)-\rho\left(y_{t}, \tau_{t}^{*}\right)\right] X / \lambda}{\left(1-\tau_{t}^{*}\right) R\left(y_{t}, \tau_{t}^{*}\right)-R\left(y_{t}, 0\right)} \equiv \hat{b}\left(y_{t} ; X / \lambda\right),
$$

and there exists a sufficiently large $\lambda$ such that, $\hat{b}\left(y_{t}, X / \lambda\right)=0$ for any $y_{t}$.

Proof. Follows from (25) and Lemma 3.

Corollary 4 The switch to the efficient tax rate $\tau_{t}^{*}$ occurs when $b_{t}^{L} \geq \hat{b}_{t}$, i.e.,

$$
b_{t}^{L} \geq \hat{b}_{t} \quad \text { if and only if } t \geq \hat{t} .
$$




\section{The Process of Development}

This section analyzes the evolution of an economy from an agricultural to an industrialbased economy. It demonstrates that the gradual decline in the importance of the agricultural sector along with an increase in the capital holdings in landlords' portfolio may alter the attitude of landlords towards educational reforms. In societies in which land is scarce or its ownership is distributed rather equally, the process of development allows the implementation of an optimal education policy, and the economy experiences a significant investment in human capital and a rapid process of development. In contrast, in societies where land is abundant and its distribution is unequal, an inefficient education policy will persist and the economy will experience a lower growth path as well as lower level of output in the long-run.

Proposition 2 The conditional evolution of output per capita, as depicted in Figure 1, is given by

$$
y_{t+1}= \begin{cases}\psi^{0}\left(y_{t}\right) \equiv\left(\beta y_{t}\right)^{\alpha} \theta_{t+1}{ }^{1-\alpha}+F\left(X, 1-\theta_{t+1}\right) & \text { for } \quad \tau=0 \\ \psi^{*}\left(y_{t}\right) \equiv\left[\left(1-\tau_{t}^{*}\right) \beta y_{t}\right]^{\alpha}\left[\theta_{t+1} h\left(\tau_{t}^{*} \beta y_{t}\right)\right]^{1-\alpha}+F\left(X, 1-\theta_{t+1}\right) & \text { for } \quad \tau=\tau^{*}\end{cases}
$$

where,

$\psi^{*}\left(y_{t}\right)>\psi^{0}\left(y_{t}\right)$ for $y_{t}>0$.

$d \psi^{j}\left(y_{t}\right) / d y_{t}>0, d^{2} \psi^{j}\left(y_{t}\right) / d y_{t}^{2}<0, \psi^{j}(0)=F(X, 1)>0, d \psi^{j}\left(y_{t}\right) / d X>0$, and

$\lim _{y_{t} \rightarrow \infty} d \psi^{j}\left(y_{t}\right) / d y_{t}=0, j=0, *$.

Proof. The proof follows from (1), (13), (15), (16) and (20), applying the envelop theorem noting that, as follows from Lemma 1 and Lemma $2, \theta_{t+1}=\arg \max y_{t+1}$ and $\tau_{t}^{*}=\arg \max y_{t+1}$.

Note that the evolution of output per capita, given schooling policy, is independent of the distribution of land and income.

Corollary 5 Given the size of land, X, there exists a unique $\bar{y}^{0}$ and a unique $\bar{y}^{*}$ such that

$$
\bar{y}^{0}=\psi^{0}\left(\bar{y}^{0}\right)
$$


and

$$
\bar{y}^{*}=\psi^{*}\left(\bar{y}^{*}\right)
$$

where $\bar{y}^{*}>\bar{y}^{0}$.

\subsection{The Dynamical System}

The evolution of output, as follows from Lemma 3 and Proposition 2, is

$$
y_{t+1}=\left\{\begin{array}{l}
\psi^{0}\left(y_{t}\right) \text { for } t<\hat{t} \\
\psi^{*}\left(y_{t}\right) \text { for } t \geq \hat{t}
\end{array}\right.
$$

The timing of the switch from a zero tax rate to the efficient tax rate $\tau_{t}^{*}$ occurs, as established in Corollary 4 once $b_{t}^{L} \geq \hat{b}_{t}$. Since $\tau_{t}=0$ for all $t<\hat{t}$, and since $\hat{b}_{t}=$ $\hat{b}\left(y_{t} ; X / \lambda\right)$, the timing of the switch, $\hat{t}$, is determined by the co evolution of $\left\{y_{t}, b_{t}^{L}\right\}$ for $\tau_{t}=0$

$$
\begin{aligned}
& y_{t+1}=\psi^{0}\left(y_{t}\right) \\
& b_{t+1}^{L}=b^{0}\left(y_{t}, b_{t}^{L}\right)
\end{aligned}
$$

Let the $b b$ locus (depicted in Figure 2) be the set of all pairs $\left(b_{t}^{L}, y_{t}\right)$ such that, for $\tau_{t}=0, b_{t}^{L}$ is in a steady state. i.e., $b_{t+1}^{L}=b_{t}^{L}$.

In order to simplify the exposition of the dynamical system it is assumed that the value of $\beta$ is sufficiently small,

$$
\beta<1 / R\left(y_{t}, 0\right) \quad \forall y_{t}
$$

where as follows from (3), (5) and Lemma $1, R\left(y_{t}, 0\right)<\infty$ for all $y_{t}$ and therefore there exists a sufficiently small $\beta$ such that A1 holds.

Lemma 5 Under A1, there exists a continuous single-valued function $\varphi\left(y_{t} ; X / \lambda\right)$,such that along the bb locus

$$
b_{t}^{L}=\varphi\left(y_{t} ; X / \lambda\right) \equiv \frac{\beta\left[w\left(y_{t}, 0\right)+\rho\left(y_{t}, 0\right) X / \lambda\right]}{1-\beta R\left(y_{t}, 0\right)}>0,
$$


where for sufficiently small $\lambda$,

$$
\varphi(0, X / \lambda)<\hat{b}(0, X / \lambda)
$$

and for $\lambda=1$

$$
\hat{b}\left(y_{t} ; X / \lambda\right)<\varphi\left(y_{t} ; X / \lambda\right) \text { for all } y_{t} .
$$

Furthermore, as depicted in Figure 2, for $\tau=0$,

$$
b_{t+1}^{L}-b_{t}^{L} \gtreqless 0 \quad \text { if and only if } b_{t}^{L} \lesseqgtr \varphi\left(y_{t} ; X / \lambda\right) \text {. }
$$

Proof. Follows from (26), A1, and Lemma 4, noting that for $\lambda=1, I_{t}^{L}=y_{t}$ and hence $\tau_{t}^{*}=\arg \max I_{t+1}^{L}$.

Let $y y^{0}$ be the locus (depicted in Figure 2) of all pairs $\left(b_{t}^{L}, y_{t}\right)$ such that, for $\tau_{t}=0$, $y_{t}$ is in a steady state equilibrium, i.e., $y_{t+1}=y_{t}$.

\section{Lemma 6}

$$
y y^{0}=\left\{\left(y_{t}, b_{t}^{L}\right): y_{t}=\bar{y}^{0}, b_{t}^{L} \in R_{+}\right\}
$$

Furthermore, as depicted in Figure 2, for $\tau=0$,

$$
y_{t+1}-y_{t} \gtreqless 0 \quad \text { if and only if } y_{t} \lesseqgtr \bar{y}^{0} \text {. }
$$

Proof. Follows from Proposition 2 and Corollary 5.

Corollary 6 For a sufficiently low $\lambda$ there exists $y>0$ such that

$$
\hat{b}(y ; X / \lambda)=\varphi(y ; X / \lambda)
$$

Proof. follows from Lemma 5 and Proposition 16.

Lemma 7 Let $\tilde{y}(X / \lambda)$ be the smallest value of $y_{t}$ such that $\hat{b}\left(y_{t} ; X / \lambda\right)=\varphi\left(y_{t} ; X / \lambda\right)$. Under A1

$$
d \tilde{y}(X / \lambda) / d \lambda \leq 0,
$$

where $\lim _{\lambda \rightarrow 0} \tilde{y}(X / \lambda)=\infty$. 
Proof. It follows from the properties of $\hat{b}\left(y_{t} ; X / \lambda\right)$ and $\varphi\left(y_{t} ; X / \lambda\right)$, noting that $w\left(y_{t}, \tau_{t}\right)$, $\rho\left(y_{t}, \tau_{t}\right)$ and $R\left(y_{t}, \tau_{t}\right)$, are independent of $\lambda$, and $\rho\left(y_{t}, 0\right)>\rho\left(y_{t}, \tau_{t}^{*}\right)$ for all $y_{t}>0$.

In order to simplify the exposition of the dynamical system it is assumed that $\tilde{y}(X / \lambda)$ is unique.

Proposition 3 The economy is characterized by:

(a) A unique globally stable steady state equilibrium, $\bar{y}^{*}$, if $\tilde{y}(X / \lambda)<\bar{y}^{0}$, that is if $\lambda$ is sufficiently large.

(b) Two locally stable steady states, $\bar{y}^{*}$ and $\bar{y}^{0}$, if $\tilde{y}(X / \lambda)>\bar{y}^{0}$, that is if $\lambda$ is sufficiently small.

Proof. Follows from the political mechanism, the definition of $\tilde{y}$ and Lemma 5 and 7 .

Theorem 1 Consider countries that are identical in all respects except for their initial land distribution.

(a) Countries that have a less equal land distribution, i.e., countries with a low level of $\lambda$, will experience a delay in the implementation of efficient education policy and will therefore experience a lower growth path.

(b) Countries characterize by a sufficiently unequal distribution of land and sufficiently low capital ownership by the landlord will permanently conduct an inefficient education policy and will therefore experience a lower growth path as well as a lower level of output in the long-run.

Proof. The theorem is a corollary of Proposition 3 and Lemma 3 and 7.

This theorem suggests that the distribution of land within and across countries affected the nature of the transition from an agrarian to an industrial economy, generating diverging growth patterns across countries. Furthermore, land abundance that was beneficial in early stages of development, brought about a hurdle for human capital accumulation and economic growth among countries that were marked by an unequal distribution of land ownership. As depicted in Figure 3, some land abundant countries 
which were associated with the club of the rich economies in the pre-industrial revolution era and were characterized by an unequal distribution of land, were overtaken in the process of industrialization by land scarce countries. The qualitative change in the role of land in the process of industrialization has brought about changes in the ranking of countries in the world income distribution.

\section{Evidence from the US High School Movement}

The central hypothesis of this research, that land inequality adversely affected the timing of education reform, is examined empirically utilizing variations in public spending on education across states in the US during the high school movement. Historical evidence from the US on education expenditures and land ownership in the period 1880-1950 suggests that land inequality had a significant adverse effect on the timing of educational reforms during the high school movement in the United States.

\subsection{The US High School Movement 1910-1940}

The qualitative changes in the education structure in the United States during the period 1900-1950 and the variations in the timing of these education reforms across states provides a potentially fertile setting for the test of the theory.

During the time period 1910-1940, the education system in US underwent a major transformation, from an insignificant secondary education to a nearly universal secondary education. ${ }^{16}$ As established by Goldin (1998) in 1910, high school graduation rates were about $9-15 \%$ in the Northeast and the Pacific regions and about $4 \%$ in the South. By 1950, graduation rates were nearly $60 \%$ in the Northeast and the Pacific regions, and about $40 \%$ in the South. Furthermore, Goldin and Katz (1997) document significant variation in the timing of these changes and their extensiveness across regions states. The average real expenditure for education per child rose by $127 \%$ in the period 1900 1920 and by $186 \%$ in the period 1920-1950 due to widening enrollment as well as the

\footnotetext{
${ }^{16}$ See the comprehensive studies of Goldin $(1998,1999)$ and Goldin and Katz (1997)
} 
higher cost associated with high school education. ${ }^{17}$

The high school movement and its qualitative effect on the structure of education in the US reflected an educational shift towards non-agricultural learning that is at the heart of the proposed hypothesis. The high school movement was undertaken with thought towards building a skilled work-force for the services and manufacturing sectors. As argued by Goldin (1999), "American high schools adapted to the needs of the modern workplace of the early twentieth century. Firms in the early 1900s began to demand workers who knew, in addition to the requisite English, skills that made them more effective managers, sales personnel, and clerical workers. Accounting, typing, shorthand, algebra, and specialized commercial courses were highly valued in the whitecollar sector. Starting in the late 1910s, some of the high-technology industries of the day, such as chemicals, wanted blue-collar craft workers who had taken plane geometry, algebra, chemistry, mechanical drawing, and electrical shop."

Goldin and Katz (1997) exploit the significant differences in high school graduation and attendance rates across states in order to examine the factors that were associated with high levels of secondary education. They find that states in the U.S. that were leaders in secondary education had high and equally distributed income and wealth and that homogeneity of economic and social conditions were conducive to the establishment of secondary education.

\subsection{Data}

In light of the proposed theory, we exploit variations in the public expenditure on education across states in the US to examine the effect of land inequality on the high school movement.

The historical data that is utilized in this study is gathered from several sources. The variables, their sources, and their method of construction are reported in the Appendix.

\footnotetext{
${ }^{17}$ Goldin (1997) estimates that the cost of educating a high-school student is twice that of an elementary-school student.
} 
- Income across states over this period is measured using estimates provided by Easterlin (1957) for 1900, 1920 and 1950. As these are the only years with available income estimates, we will be limited to consideration of these years alone.

- The characterization of the timing of the high school movement is based on the classification of Goldin (1998). As is reflected from their study, in 1900 the highschool movement has just barely begun, by 1920 it had been well underway, and by 1950 most of the changes in secondary education had been completed.

- In order to capture the effect of land inequality on the high school movement, we examine the effect of the land inequality prior to the onset on the process on the variations in the high school movement across states. The US census of 1880 is therefore used in order to construct the Gini coefficient on land distribution.

\subsection{Testable Predictions}

According to the proposed theory, the nature of the relationship between land inequality and public expenditure on education changes over time as states develop. In early stages of development (i.e. prior to the onset of the high school movement in about 1910), the level of development of each state does not necessitate investment in high school education. Hence, land inequality would be expected to have limited effect on the educational expenditures, and variations in educational expenditures would reflect mostly differences in income across states. In later stages, however, as argued by Goldin (1999), high school education was needed in order to produce skilled worker for the industrial and the service sectors. At this stage, due to the lower complementarity of high school education with the agricultural sector, the concentration of land would be expected to adversely affect educational expenditure, and variation across states reflected variations in land inequality as well as in income across states. Ultimately, as the necessary skills were formed by 1940, variations in educational expenditures across states would be expected to reflect mostly variations in income.

Hence, in the context of the available data, the prediction of the theory is that: 
(a) There exits an insignificant relationship between initial land conditions and education expenditures in either 1900 or in 1950, controlling for income.

(b) There exist a significant negative relationship between land inequality and education expenditures in 1920, controlling for income.

\subsection{Empirical Specification and Results}

The empirical analysis is based on simple cross-sectional OLS regressions of states in each of the years 1900, 1920, and 1950. ${ }^{18}$ Expenditure on education per child is the dependent variable in each case. Income per capita in the years 1900, 1920 and 1950, respectively, and the Gini coefficient for farm size distribution in 1880 are included as explanatory variables. Land inequality in 1880, rather than the contemporary measure of land inequality, is used for each of the 3 time periods, in order to capture the long-term impacts of initial land inequality and to avoid the endogeneity associated with changes in land distribution over time.

In addition we include the following controls: value per farm in 1880, the interaction of value per farm with the Gini coefficient, the percentage of population that is black, the percentage of population that is urban, and a dummy variable indicating if a state is in the West. ${ }^{19}$

In order to separate the effect of land inequality from other characteristics of land, "value per farm" and in some specifications its interaction with land inequality are included as a control variables. The percent of the population that resides in an urban environment is included to control for several possible influences: (a) economies of scale in education that are more pronounced in urban areas, (b) variations in teacher salaries and

\footnotetext{
${ }^{18}$ It should be noted that another avenue of empirical investigation would be to examine the differences in land conditions within states over time and their impacts on education expenditures. This research avenue, however, would generate severe problems of endogeneity. Furthermore, variations in land inequality over time within states are smaller than that across states at any given time and are too subtle to offer much explanatory power.

${ }^{19}$ Data on Income inequality in the US over this period is not available and thus is not part of our control variables. Goldin and Katz (1997) constructed a proxy for wealth inequality across states in this period based on the number of car per capita.
} 
thus educational expenditures vary between rural-intensive and urban-intensive states, and (c) the increased demand for education in urban-intensive states.

The dummy variable for the West is designed to capture the westward expansion of settlements in the US. During the early part of the period of study, the western states were relatively new to the U.S. and very lightly populated. ${ }^{20}$ Easterlin (1961) describes the western economy having two characteristics. The first is a high portion of the workforce in mining as opposed to agriculture or manufacturing ${ }^{21}$ the second is a very low dependency ratio. The West dummy is designed to capture differential effects that can be attributed to these influences. As will become apparent, this control does not affect the qualitative results. The percentage of population that is black is designed to capture the differential effects of racial policies on educational expenditures or lingering effects of Reconstruction.

Tables 2-4 report the outcome of the cross-sectional regressions for each of the years 1900, 1920 and 1950. Column (1) in each table shows the simple regression of expenditure per child on income per capita. In 1900, the R-squared of this regression is roughly $85 \%$. In contrast, in 1920 the R-squared of the same regression is only 43\%. Hence, in 1920, there are wide differences in education expenditure beyond those explained simply by income per capita. As is apparent from columns (4)-(6) land conditions are one of the significant determinants of the variations in educational expenditure differences in $1920 .^{22}$

Columns (2) and (3) in each table include further controls for urbanization, percentage black, and the west dummy. The effect of the percentage of black in the population on expenditures per child is significantly negative under some specifications and insignificant in all others. This is likely to be an outcome of the low enrollment rates of black students, as well as the under-funding of black schools across the southern states. The

\footnotetext{
${ }^{20}$ Their low population density would potentially raise the amount of resources necessary to educate children to the same level as a state further east with higher population and smaller distances to cover. This is particularly important given the rising prevalence of rural busing in this period.

${ }^{21}$ Although the complementarity between human capital and the agricultural and the mining sectors are rather similar, land inequality does not capture the concentration of ownership in the mining sector.

${ }^{22}$ For reasons explained in the Appendix, the 1900 regression includes only 43 states while the 1920 and 1950 regressions included 45 states. Restricting the 1920 and 1950 regressions to the same 43 states as in 1900 has no effect on the results.
} 
west dummy has a significant positive impact in both 1920 and 1950. This is consistent with the findings of Goldin (1999) that enrollment rates in the west were generally higher than in most other areas of the U.S.

The effect of land inequality on educational expenditure, controlling for other land characteristics, is captured in columns (4)-(6) of Tables 2-4. As depicted in Table 2, for the year 1900, land inequality has an insignificant effect on educational expenditure, consistently with the theory's testable predictions. However, as depicted in Table 3 for the year 1920, and consistently with the testable predictions, land inequality as captured by the Gini index on farm size in 1880, has a significant negative effect in all specifications. In the year 1950, as depicted in Table 4, the impacts of land inequality on educational expenditure is insignificant. Consistently with the testable predictions, once the high school movement had been completed, the significant negative impact of land inequality seen in 1920 is no longer present. ${ }^{23}$

It is interesting to note that as is apparent from all columns of Tables 2-4, the positive effect of income per capita on educational expenditure increases over the entire period. Hence, consistent with the proposed theory, land inequality determines the timing of educational reforms, but income per capita determines the level of educational expenditures. The rising importance of education over the period 1900-1950 magnified the role of income per capita in the determination of variations in educational expenditure across states.

Interestingly, the inclusion of land characteristics removes much of the significance and size of the coefficient on the percentage of black in the population. It appears that some of the racial differences in education outcomes worked through the poor land distributions left behind by the plantation system in the south. (See Margo [1990] for further discussion of the relationship between race and education in the South).

\footnotetext{
${ }^{23}$ The results for 1920 are consistent with the finding of Goldin and Katz (1997) that inequality is associated with poor education outcomes during the high school movement. The proposed theory identifies an explicit mechanism through which land inequality adversely affected education outcomes.
} 


\section{Concluding Remarks}

The proposed theory suggests that land inequality affected the nature of the transition from an agrarian to an industrial economy generating diverging growth patterns across countries. Land abundance, which was beneficial in early stages of development, generated in later stages a hurdle for human capital accumulation and economic growth among countries in which land ownership was unequally distributed. The qualitative change in the role of land in the process of industrialization affected the transition to modern growth and has brought about changes in the ranking of countries in the world income distribution. Some land abundant countries that were associated with the club of the rich economies in the pre-industrial revolution era and were marked by an unequal distribution of land, were overtaken in the process of industrialization by land scarce countries and were dominated by other land abundant economies in which land distribution was rather equal.

The central hypothesis of this research that land inequality adversely affected the timing of education reform is examined empirically, utilizing variations in public spending on education across states in the US during the high school movement. Historical evidence from the US on education expenditures and land ownership in the period 1880-1950 suggests that land inequality had a significant adverse effect on the timing of educational reforms during the high school movement in the United States.

The theory abstracts from the sources of distribution of population density across countries in the pre-industrialization era. The Malthusian mechanism, that positively links population size to effective resources in each region, suggests that the distribution of population density in the world economy should reflect in the long run the distribution of productive land across the globe. Hence, one could have argued that significant economic variations in effective land per capita in the long run are unlikely. Nevertheless, there are several sources of variations in effective resources per-capita in the pre-industrial world. First, due to rapid technological diffusion across countries and continents in the era of "innovations and discoveries" (e.g., via colonialism) population size 
in the technologically receiving countries has not completed their adjustment prior to industrialization, and population density in several regions were therefore below their long-run level. Second, inequality in the distribution of land ownership within countries (due to geographical conditions, for instance) prevented population density from fully reflecting the productivity of land. Variations in population density across the globe may therefore reflect variations in climate, settlement date, disease, colonization, and inequality.

In contrast to the recent literature that attempts to disassociate the role of geography and institutions in economic development, the theory suggest that geographical conditions and institutions are intimately linked. Geographical conditions that were associated with increasing returns in agricultural, or in the extraction of natural resources led to the emergence of a class of wealthy landlords that ultimately affected adversely the implementation of an efficient institution of public education. Furthermore, geographical conditions were the prime determinant of the timing of the agricultural revolution [Diamond (1997)] and due to the interaction between technological progress and population growth [Malthus (1789) and Boserup (1965)] the cause of variation in the level of technology and population density, in geographically isolated regions despite similar levels of output per capita. Hence, the link that was created between geographically isolated areas in the era of discoveries, and the associated diffusion of technology, generated geographically-based variations in effective land per capita, that according to the proposed theory led to the implementation of different institutions of public education.

The paper implies that differences in the evolution of social structures across countries may reflect differences in land abundance and its distribution. In particular, the dichotomy between workers and capitalists is more likely to persist in land abundant economies in which land ownership is unequally distributed. As argued by Galor and Moav (2000), due to the complementarity between physical and human capital in production, the Capitalists were among the prime beneficiaries of the accumulation of human capital by the masses. They had therefore the incentive to financially support public education that would sustain their profit rates and would improve their economic well 
being, although would ultimately undermine their dynasty's position in the social ladder and would bring about the demise of the capitalist-workers class structure. As implied by the current research, the timing and the degree of this social transformation depend on the economic interest of landlords. In contrast to the Marxian hypothesis, this paper suggests that workers and capitalists are the natural economic allies that share an interest in industrial development and therefore in the implementation of growth enhancing universal public education, whereas landlords are the prime hurdle. 


\section{Appendix - Data Sources}

Education Expenditures - This is obtained from the Historical Statistics of the United States for 1920 and 1950, and from the U.S. Bureau of Education, Report of the Commissioner of Education for 1900. These expenditures are reported in current dollars, and are converted to 1929 dollars to match the income per capita estimates.

Expenditure per child - The number of relevant children in a year is taken from the U.S. Census. The relevant age ranges are 5-20 years in 1900, 7-20 years in 1920, and 5-19 years in1950. Although, the age ranges in each year are not consistent, we assume that they remain comparable over time. Furthermore, it should be noted that since we are not comparing expenditure per child across periods, these differences in reference population are not significant.

Value per farm - Obtained from the U.S. Census in the relevant year. The exact measure is the value of land and land improvements (in dollars) for each state. This value is divided by the number of farms in order to obtain the value per farm.

Gini coefficient of farm distribution - This measure was constructed for each year from farm distribution data in the U.S. Census. For 1950 and 1920, the Census reports the distribution of number of farms and total acreage of farms by bin size. This allows for a straightforward estimation of a Gini coefficient. The bins used in 1950 are more refined than the ones in 1920. In 1900 and 1880, the Census only reports the distribution of number of farms, not their total acreage. In order to estimate a Gini, assumptions must be made regarding the average size of a farm within each bin. For this, we turn to the 1920 data as a guide. In most cases, the average farm size is very close to the average expected if farms were distributed uniformly over the bin (for example, the average farm size in 1920 in the 20-50 acre bin is close to 35 acres). Therefore, in 1880 we use the average size expected in each bin as the actual average size in each bin. The only remaining complication is in the case where the bin for farms greater than 1000 acres. We assume that the average size of farms in this bin in 1880 is 1800 acres. These values are lower than that in 1920 (2500 acres), but when used these values make the 
total acreage across all bins come out very closely to the actual total farmland acreage across states. Once these assumptions are made, Gini coefficients can be estimated for 1880. Full data concerning the calculation of these Gini coefficients is available from the authors upon request.

Percent black - This variable is taken from the U.S. Census in the relevant years.

West Dummy - This variable equals 1 for the following states: Arizona, California, Colorado, Idaho, Montana, Nevada, New Mexico, Oregon, Utah, and Washington, and is 0 for all others states.

Income per capita - These are estimates by Easterlin from Population Redistribution and Economic Growth: United States, 1870-1950, edited by Kuznets and Thomas (1957). See their work for descriptions of how this data is constructed.

Excluded states - In the regressions presented, the number of states was either 43 or 45 . States that were excluded were generally not part of the U.S. in the time period or had serious data issues (particularly in 1880 or 1900). Those states excluded in the 1900 regressions are: Alaska, Arizona, Hawaii, New Mexico, North Dakota, Oklahoma, and South Dakota. Those states excluded from the 1920 and 1950 regressions are Alaska, Hawaii, North Dakota, Oklahoma, and South Dakota.

Percent Urban - The fraction of the population residing in urban areas, where urban area is defined as any city/town with more than 4,000 people. It is calculated based on the corresponding U.S. Census. 


\section{References}

[1] Acemoglu, D. and S. Johnson, Robinson, J. A (2002), "Reversal of Fortune: Geography and Institutions in the Making of the Modern World Income Distribution " Quarterly Journal of Economics, 117.

[2] Besley T, Burgess R (2000) "Land reform, poverty reduction, and growth: Evidence from India" Quarterly Journal of Economics 115 (2): 389-430 May.

[3] Boserup, E., (1965). The Conditions of Agricultural Progress Aldine Publishing Company, Chicago, Il.

[4] Benabou, R. (2000), "Unequal Societies: Income Distribution and the Social Contract, American Economic Review, 90, 96-129.

[5] Bertocchi, G.,. (2002), "The Law of Primogeniture and the Transition from Landed Aristocracy to Industrial Democracy," University of Medena.

[6] Caselli, F., and W.J. Coleman, (2001), "The US structural transformation and regional convergence: A reinterpretation," Journal of Political Economy, 109, 584616

[7] Coatsworth, John H. "Notes on the Comparative Economic History of Latin America and the United States." In Development and Underdevelopment in America, Bernecker, Walther and Hans Werner Tobler, Eds. Walter de Gruyter. 1993

[8] Deninger K, and Squire, L (1998), "New Ways of Looking at Old Issues: Inequality and Growth", Journal of Development Economics, 57, 259-287.

[9] Diamond, J. (1997).Guns, Germs, and Steel: The Fates of Human Societies.

[10] Easterlin, Richard A.. 1957 "Regional Growth of Income: Long Term Tendencies." in Population Redistribution and Economic Growth: United States, 1870-1950, Vol. 2: Analysis of Economic Change. Edited by Simon Kuznets, Ann Ratner Miller, and Richard A. Easterlin. American Philosophical Society: Philadelphia.

[11] Eckert, C.J. Korea Old and New: A History. Seoul. 1990.

[12] Engerman, Stanley L., and Kenneth L. Sokoloff. 1997. "Factor Endowments, Institutions, and Differential Paths of Growth Among New World Economies: A View from Economic Historians of the United States." In Stephen Haber, ed., How Latin America Fell Behind. Stanford, Calif.: Stanford University Press 
[13] Estevo, Gustavo. The Struggle for Rural Mexico. Bergin and Garvey, South Hadley, MA. 1983.

[14] Fox. "Agricultural Wages in England." Journal of the Royal Statistical Society, Vol. 66. London. 1903.

[15] Galor, O. and Zeira, J. (1993), 'Income Distribution and Macroeconomics', Review of Economic Studies, vol. 60, pp. 35-52.

[16] Galor, Oded and Weil, David N. (2000) "Population, Technology and Growth: From the Malthusian Regime to the Demographic Transition," American Economic Review, 90(4), pp. 806-828.

[17] Galor, O. and O. Moav (2002), "Natural Selection and the Origin of Economic Growth," Quarterly Journal of Economics, 117.

[18] Galor, O. and O. Moav (2000), Das Human Kapital".

[19] Gerber, J., (1991), "Public-School Expenditures in the Palntation Sates, 1910," Explorations in Economic History, 28, 309-322.

[20] Goldin, C., (1999) "Egalitarianism and the Returns to Education During the Great Transformation of American Education". The Journal of Political Economy, 107(6): S65-S94.

[21] Goldin, C., (1998), "America's Graduation from High School: The Evolution and Spread of Secondary Schooling in the Twentieth Century," Journal of Economic History. 58: 345-74.

[22] Goldin, C. and L. F. Katz (1998), 'The Origins of Technology-Skill Complementary', Quarterly Journal of Economics, vol. 113, pp.693-732.

[23] Goldin, C. and Katz, L. F., (1997), "Why the United States Led in Education: Lessons from Secondary School Expansion, 1910 to 1940." NBER Working Paper no. 6144 .

[24] Gylfason T. (2001). "Natural Resources, Education, and Economic Development," European Economic Review (45)4-6 847-859.

[25] Inter-university Consortium for Political and Social Research. Historical, Demographic, Economic and Social Data: The United States, 1790-1970 [Computer file]. Ann Arbor, MI. 
[26] Kuznets, S. (1955), 'Economic Growth and Income Equality', American Economic Review, vol. 45, pp. 1-28.

[27] Lane P.R. and A. Tornel (1996). "Power, Growth and the Voracity Effect," Journal of Economic Growth, 1, 213-242.

[28] Loveman, Brian. Allende's Chile: Political Economy of the Peaceful Road to Disaster. Latin American Studies Association. 1974.

[29] Lucas, Robert E. , Jr. (2000). "Some Macroeconomics for the 21st Century," Journal of Economic Perspectives, 14, 159-168.

[30] Maddison, Angus. Monitoring the World Economy 1820-1992. OECD. 1995

[31] Margo, Robert A.. 1990. Race and Schooling in the South, 1880-1950: An Economic History. University of Chicago Press: Chicago.

[32] Mokyr, Joel. The Lever of Riches, New York: Oxford University Press, 1990.

[33] North, Douglas C. (1981) Structure and Change in Economic History, W.W. Norton $\&$ Co., New York.

[34] Perotti, R. (1996), 'Growth, Income Distribution, and Democracy: What the Data Say', Journal of Economic Growth, vol. 1, pp. 149-87.

[35] Persson, T. and G. Tabellini, Political Economics: Explaining Economic Policy, MIT Press 2000.

[36] Pritchett, L. (1997), "Divergence, Big Time," Journal of Economic Perspectives, $11,3-18$.

[37] Quah, D. (1997). "Empirics for Growth and Distribution: Stratification, Polarization and Convergence Clubs," Journal of Economic Growth, 2, 27-60.

[38] Ringer, F. (1979) Education and Society in Modern Europe, Indiana University Press, Bloomington.

[39] Sachs, Jeffrey and Andrew M. Warner. (1995). "Natural Resource Abundance and Economic Growth." NBER Working Paper 5398.

[40] Sokoloff, Kenneth. "Institutions, Factor Endowments, and Paths of Development in the New World." Villa Borsig Workshop Series. www.dse.de/ef/instn/sokoloff.htm. 2000 . 
[41] Rodrigues, F. and Sachs, J.D. (1999) "Why do Resource Abundance Economies Grow More slowly?" Journal of Economic Growth, 4, 277 - 304.

[42] U.S. Bureau of Education. 1870-1950. Report of the Commissioner of Education. Government Printing Office: Washington D.C..

[43] U.S. Bureau of the Census. 1989. Historical Statistics of the United States: Colonial Times to 1970. Kraus International Publications: White Plains, NY.

[44] U.S. Department of Agriculture, Profile of Hired Farmworkers, 1998 Annual Averages.

[45] Wright, D.G. (1970) Democracy and Reform 1815-1885, Longman, London.

[46] Yoong, D.J. 2000 "Land Reform, Income Redistribution, and Agricultural Production in Korea." Economic Development and Cultural Change. 48(2) 


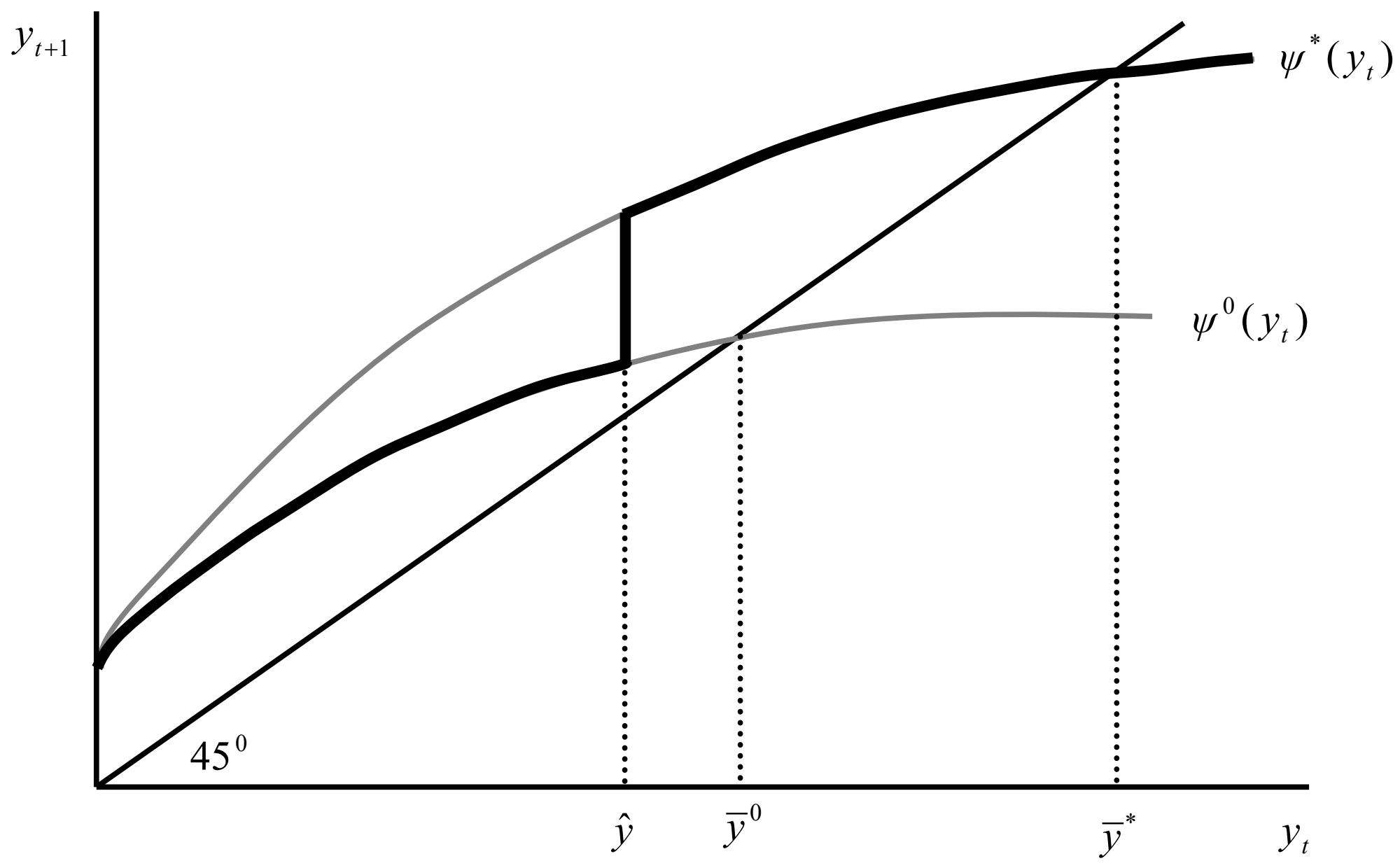

Figure 1

The evolution of output and before and after the implementation of the education reform 


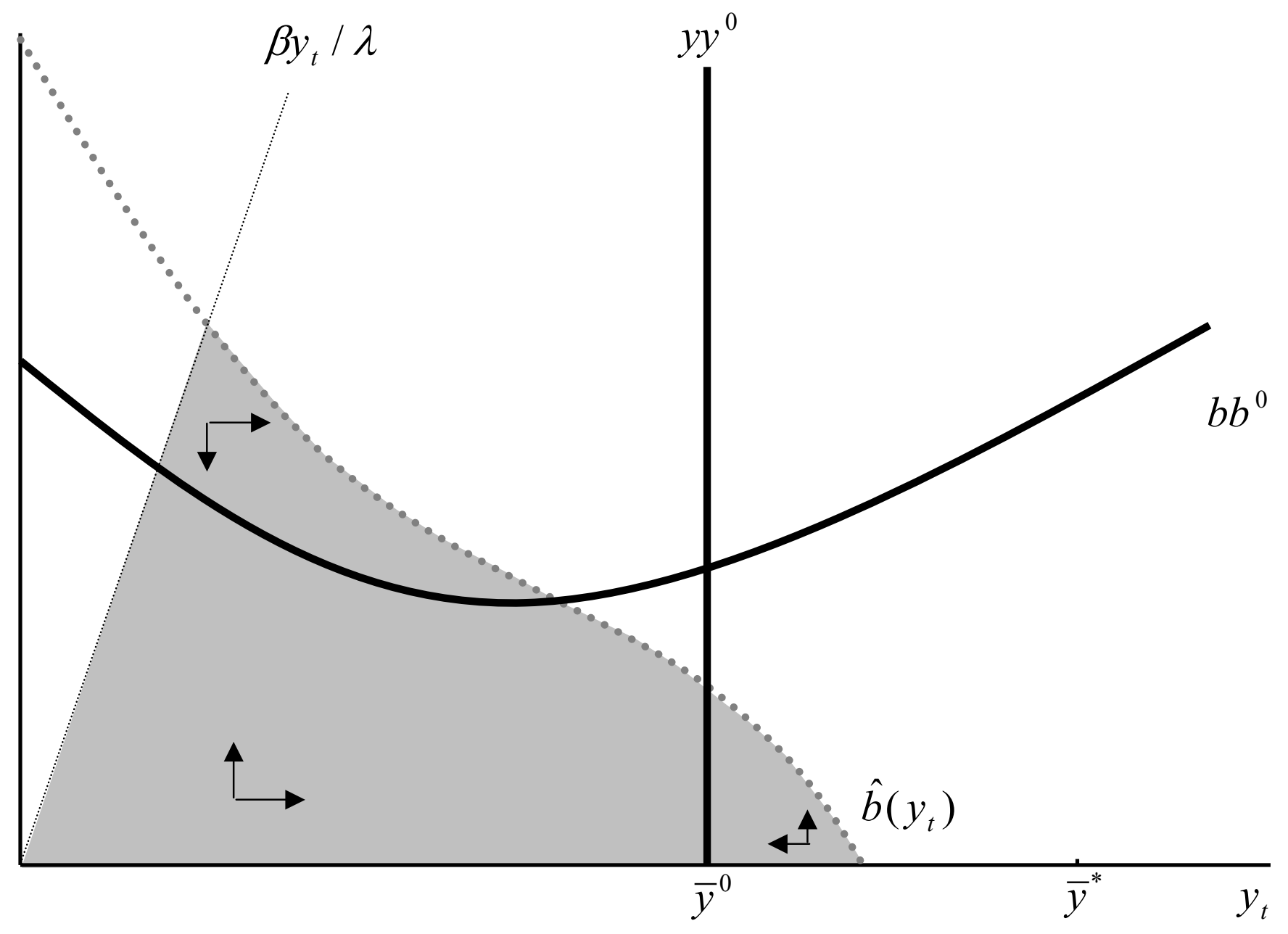

Figure 2

The Evolution of output and Landowner's bequest prior to the implementation of education reform 


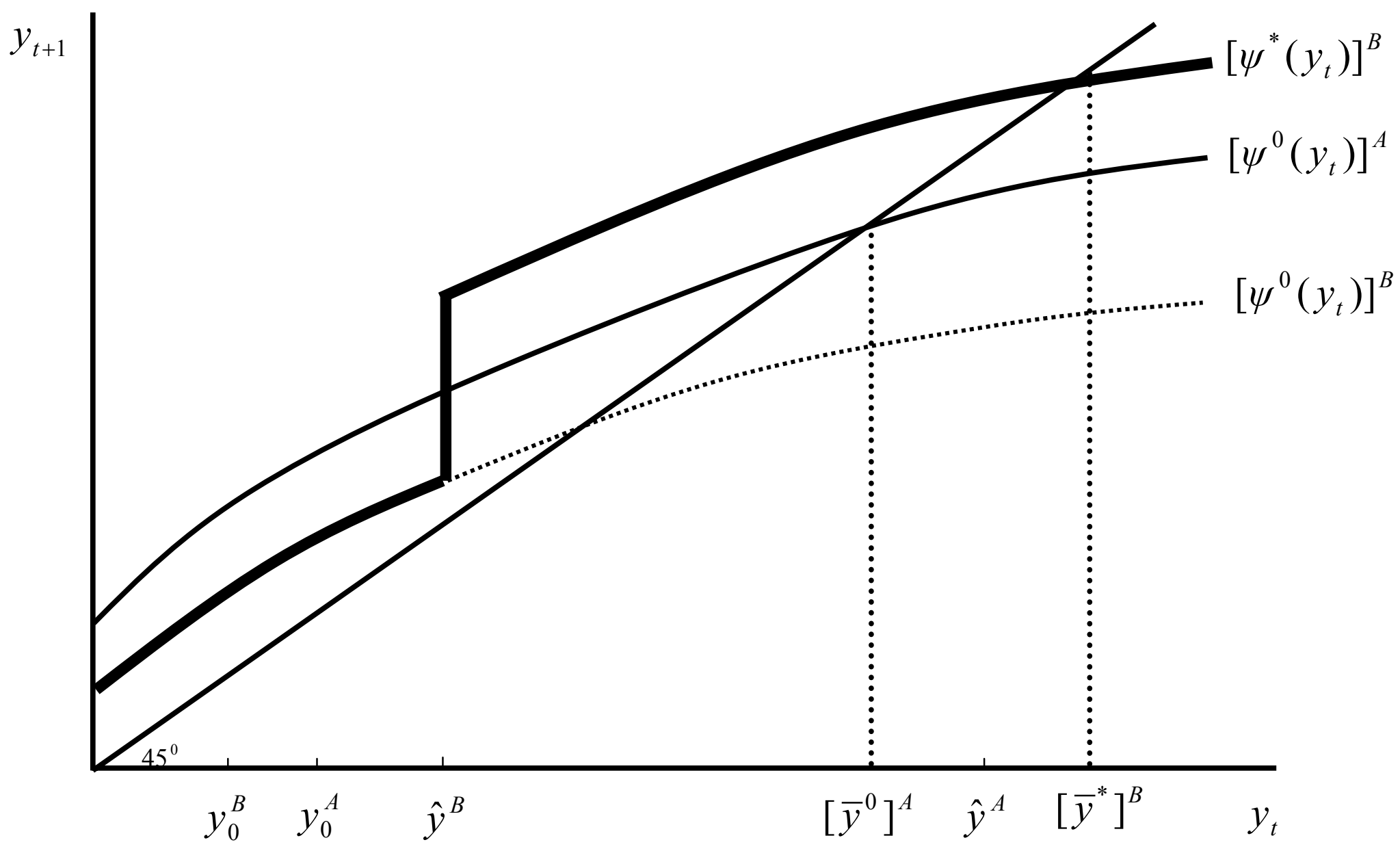

Figure 3

Overtaking - country A is relatively richer in land, however, due to land inequality it fails to implement efficient schooling and is overtaken by country B. Alternatively, for a lower degree of inequality, country A will eventually implement education reforms and ultimately takeover country B (not captured in the figure). 
Table 1: GDP per Capita Relative to the US

\begin{tabular}{|c|c|c|c|c|c|c|c|c|c|}
\hline Country & Note & 1870 & 1900 & 1913 & 1930 & 1940 & 1950 & 1960 & 1994 \\
\hline Australia & & 154.70 & 104.96 & 103.73 & 77.04 & 84.64 & 75.40 & 76.29 & 75.80 \\
\hline USA & & 100.00 & 100.00 & 100.00 & 100.00 & 100.00 & 100.00 & 100.00 & 100.00 \\
\hline New Zealand & & 126.78 & 105.47 & 97.57 & 80.14 & 90.23 & 88.74 & 84.79 & 66.84 \\
\hline UK & & 132.80 & 112.13 & 94.82 & 83.52 & 93.27 & 71.52 & 76.57 & 72.54 \\
\hline Canada & & 65.93 & 67.33 & 79.39 & 73.28 & 72.47 & 73.61 & 75.57 & 81.31 \\
\hline Switzerland & & 88.40 & 86.21 & 79.27 & 99.04 & 89.90 & 93.38 & 109.77 & 92.29 \\
\hline Belgium & & 107.45 & 89.16 & 78.39 & 78.34 & 63.62 & 55.84 & 60.56 & 76.32 \\
\hline Netherlands & & 107.45 & 86.25 & 74.43 & 87.89 & 67.17 & 61.11 & 72.23 & 76.00 \\
\hline Germany & & 77.86 & 76.51 & 72.23 & 65.10 & 79.01 & 44.72 & 75.61 & 84.62 \\
\hline Argentina & & 53.36 & 67.29 & 71.55 & 65.59 & 59.33 & 52.09 & 49.66 & 37.10 \\
\hline Denmark & & 78.43 & 70.85 & 70.93 & 82.60 & 70.13 & 69.81 & 75.73 & 85.54 \\
\hline Austria & & 76.31 & 70.83 & 65.72 & 58.04 & 56.78 & 38.97 & 58.62 & 76.59 \\
\hline France & & 75.62 & 69.56 & 65.05 & 72.17 & 57.05 & 54.54 & 66.76 & 79.61 \\
\hline Sweden & & 67.72 & 62.52 & 58.34 & 63.30 & 69.22 & 70.39 & 77.62 & 74.04 \\
\hline Ireland & $\star \star *$ & 72.16 & 60.91 & 51.50 & 46.35 & 44.40 & 36.75 & 39.02 & 55.94 \\
\hline Chile & & & 47.58 & 50.01 & 50.53 & 46.44 & 39.98 & 38.45 & 34.40 \\
\hline Italy & & 59.71 & 42.63 & 47.24 & 45.88 & 48.86 & 35.78 & 51.72 & 72.68 \\
\hline Norway & & 53.03 & 43.02 & 42.87 & 54.29 & 52.98 & 51.91 & 58.51 & 81.40 \\
\hline Spain & $\star \star \star \star$ & 56.00 & 49.80 & 42.49 & 47.38 & 28.81 & 25.04 & 30.71 & 55.58 \\
\hline Finland & & 45.05 & 39.55 & 38.63 & 41.62 & 44.57 & 43.15 & 54.06 & 65.48 \\
\hline Greece & $\star \star \star *$ & & & 30.54 & 38.36 & 38.86 & 20.38 & 28.63 & 45.04 \\
\hline Mexico & & 28.90 & 28.25 & 27.64 & 22.04 & 22.17 & 21.78 & 24.85 & 22.59 \\
\hline South Africa & ** & & & 27.34 & & & 23.51 & 23.44 & 15.29 \\
\hline Philippines & * & & 25.22 & 26.72 & & 21.33 & 13.51 & 13.29 & 9.81 \\
\hline Portugal & $* * *$ & 44.16 & 34.38 & 25.51 & 24.69 & 24.32 & 22.27 & 27.65 & 49.11 \\
\hline Japan & & 30.16 & 27.71 & 25.14 & 28.62 & 39.40 & 19.57 & 34.66 & 86.42 \\
\hline Colombia & & & 23.75 & 23.29 & 23.70 & 27.00 & 21.82 & 22.33 & 23.74 \\
\hline Venezuela & & & 20.04 & 20.80 & 55.37 & 57.64 & 77.55 & 86.89 & 37.17 \\
\hline Peru & & & 19.95 & 19.54 & 22.78 & 25.98 & 23.64 & 27.01 & 14.32 \\
\hline Turkey & $\star \star \star \star ~$ & & & 18.45 & 15.37 & 19.36 & 13.57 & 16.09 & 18.90 \\
\hline S. Korea & * & & 20.75 & 17.86 & 18.86 & 23.50 & 9.15 & 11.63 & 44.35 \\
\hline Indonesia & * & 26.74 & 18.19 & 17.28 & 19.26 & 16.19 & 9.13 & 10.10 & 12.18 \\
\hline Thailand & * & 29.18 & 19.82 & 15.94 & & 11.86 & 8.86 & 9.19 & 20.80 \\
\hline
\end{tabular}




\begin{tabular}{|c|c|c|c|c|c|c|c|c|c|}
\hline Brazil & & 30.12 & 17.19 & 15.81 & 17.06 & 18.55 & 17.48 & 20.86 & 21.54 \\
\hline Taiwan & * & & 18.53 & 14.96 & 17.88 & 18.81 & 9.63 & 12.50 & 51.35 \\
\hline Pakistan & * & & 16.77 & 13.74 & & 9.69 & 6.79 & 5.91 & 7.28 \\
\hline China & * & 21.29 & 15.92 & 12.96 & 12.64 & 11.09 & 6.41 & 7.84 & 13.73 \\
\hline India & * & 22.71 & 15.26 & 12.49 & 10.51 & 8.82 & 6.24 & 6.57 & 5.97 \\
\hline Ghana & ** & & 15.67 & 12.21 & & & 12.46 & 11.01 & 4.46 \\
\hline Burma & * & & & 11.97 & & 9.76 & 4.11 & 4.90 & 3.31 \\
\hline Bangladesh & & & 14.18 & 11.63 & & 8.15 & 5.76 & 4.79 & 3.19 \\
\hline Egypt & ** & & 12.43 & 9.57 & & & 5.40 & 6.36 & 8.54 \\
\hline Morocco & ** & & & & & & 16.83 & 13.50 & 10.31 \\
\hline Nigeria & ** & & & & & & 5.71 & 5.76 & 5.10 \\
\hline Ivory Coast & ** & & & & & & 8.97 & 9.39 & 5.02 \\
\hline Kenya & ** & & & & & & 6.36 & 6.41 & 4.67 \\
\hline Tanzania & ** & & & & & & 4.46 & 4.45 & 2.66 \\
\hline Zaire & ** & & & & & & 6.64 & 7.22 & 1.56 \\
\hline Ethiopia & ** & & & & & & 2.89 & 2.70 & 1.33 \\
\hline * & \multicolumn{9}{|c|}{1938 used for 1940,1992 used for 1994} \\
\hline ** & \multicolumn{9}{|c|}{1992 used for 1994} \\
\hline *** & \multicolumn{9}{|c|}{1920 used for 1930,1938 used for 1940} \\
\hline & & 1995) & & & & & & & \\
\hline
\end{tabular}


Table 2 - 1900

\begin{tabular}{|c|c|c|c|c|c|c|}
\hline Exp Variable & $\begin{array}{c}(1) \\
\text { Exp/Child } \\
\text { in } 1900\end{array}$ & $\begin{array}{c}(2) \\
\text { Exp/Child } \\
\text { in } 1900\end{array}$ & $\begin{array}{c}(3) \\
\text { Exp/Child } \\
\text { in } 1900\end{array}$ & $\begin{array}{c}(4) \\
\text { Exp/Child } \\
\text { in } 1900\end{array}$ & $\begin{array}{c}(5) \\
\text { Exp/Child } \\
\text { in } 1900\end{array}$ & $\begin{array}{c}(6) \\
\text { Exp/Child } \\
\text { in } 1900\end{array}$ \\
\hline $\begin{array}{l}\text { Income per capita } \\
\text { (in 1900) }\end{array}$ & $\begin{array}{l}0.0515^{* *} \\
(15.41)\end{array}$ & $\begin{array}{c}0.0473^{\text {** }} \\
(9.25)\end{array}$ & $\begin{array}{c}0.0310 \text { ** } \\
(3.90)\end{array}$ & $\begin{array}{c}0.0253^{\text {** }} \\
(2.98)\end{array}$ & $\begin{array}{c}0.0250 \text { ** } \\
(2.88)\end{array}$ & $\begin{array}{c}0.0344^{\text {** }} \\
(6.00)\end{array}$ \\
\hline $\begin{array}{l}\text { Percent Urban } \\
\text { (in 1900) }\end{array}$ & & $\begin{array}{r}4.3893 \\
(0.96)\end{array}$ & $\begin{array}{r}6.9113 \\
(1.36)\end{array}$ & $\begin{array}{r}6.0582 \\
(1.07)\end{array}$ & $\begin{array}{r}6.4669 \\
(1.07)\end{array}$ & $\begin{array}{r}1.4306 \\
(0.29)\end{array}$ \\
\hline $\begin{array}{l}\text { Percent Black } \\
\text { (in 1900) }\end{array}$ & & & $\begin{array}{c}-16.3616 \text { ** } \\
(3.81)\end{array}$ & $\begin{array}{c}-10.3195 * \\
(1.72)\end{array}$ & $\begin{array}{r}-9.8481 \\
(1.53)\end{array}$ & $\begin{array}{c}-11.0278 * \\
(1.70)\end{array}$ \\
\hline West Dummy & & & $\begin{array}{r}2.3209 \\
(1.03)\end{array}$ & $\begin{array}{r}3.6219 \\
(1.47)\end{array}$ & $\begin{array}{r}3.5902 \\
(1.44)\end{array}$ & \\
\hline $\begin{array}{l}\text { Gini of farm size } \\
\text { (in 1880) }\end{array}$ & & & & $\begin{array}{r}-10.3157 \\
(1.22)\end{array}$ & $\begin{array}{r}-12.9530 \\
(0.90)\end{array}$ & $\begin{array}{r}8.4675 \\
(0.59)\end{array}$ \\
\hline $\begin{array}{l}\text { Value per farm } \\
\text { (in 1880) }\end{array}$ & & & & $\begin{array}{r}0.0009 \\
(1.67)\end{array}$ & $\begin{array}{r}0.0005 \\
(0.26)\end{array}$ & $\begin{array}{r}0.0003 \\
(0.13)\end{array}$ \\
\hline $\begin{array}{l}\text { Value } \times \text { Gini } \\
\text { (in 1880) }\end{array}$ & & & & & $\begin{array}{r}0.0009 \\
(0.23)\end{array}$ & $\begin{array}{r}0.0013 \\
(0.30)\end{array}$ \\
\hline Constant & $\begin{array}{c}-3.6445 * * \\
(2.39)\end{array}$ & $\begin{array}{c}-3.13466^{* *} \\
(1.98)\end{array}$ & $\begin{array}{c}4.6074 \text { * } \\
(1.79)\end{array}$ & $\begin{array}{l}7.8658 \text { ** } \\
(1.98)\end{array}$ & $\begin{array}{r}9.0543 \\
(1.37)\end{array}$ & $\begin{array}{r}5.8511 \\
(0.93)\end{array}$ \\
\hline Adj R-squared & 0.8492 & 0.8356 & 0.8764 & 0.8813 & 0.8779 & 0.8741 \\
\hline total observations & 43 & 43 & 43 & 43 & 43 & 43 \\
\hline Method & OLS & OLS & OLS & OLS & OLS & OLS \\
\hline
\end{tabular}

Absolute values of t-ratios are given in parentheses

** indicates significance at $5 \%$

* indicates significance of $10 \%$ 
Table 3 - 1920

\begin{tabular}{|c|c|c|c|c|c|c|}
\hline Exp Variable & $\begin{array}{c}(1) \\
\text { Exp/Child } \\
\text { in } 1920\end{array}$ & $\begin{array}{c}(2) \\
\text { Exp/Child } \\
\text { in } 1920\end{array}$ & $\begin{array}{c}(3) \\
\text { Exp/Child } \\
\text { in } 1920\end{array}$ & $\begin{array}{c}(4) \\
\text { Exp/Child } \\
\text { in } 1920\end{array}$ & $\begin{array}{c}(5) \\
\text { Exp/Child } \\
\text { in } 1920\end{array}$ & $\begin{array}{c}(6) \\
\text { Exp/Child } \\
\text { in } 1920\end{array}$ \\
\hline $\begin{array}{l}\text { Income per capita } \\
\text { (in 1920) }\end{array}$ & $\begin{array}{c}0.0833 \text { ** } \\
(5.81)\end{array}$ & $\begin{array}{c}0.1415^{\text {** }} \\
(7.83)\end{array}$ & $\begin{array}{c}0.0606 \text { ** } \\
(2.97)\end{array}$ & $\begin{array}{c}0.0743^{\text {** }} \\
(3.61)\end{array}$ & $\begin{array}{c}0.0725 \text { ** } \\
(3.48)\end{array}$ & $\begin{array}{c}0.1089 \text { ** } \\
(4.68)\end{array}$ \\
\hline $\begin{array}{l}\text { Percent Urban } \\
\text { (in 1920) }\end{array}$ & & $\begin{array}{c}-63.2109 * * \\
(4.33)\end{array}$ & $\begin{array}{c}-29.7652 \text { ** } \\
(2.10)\end{array}$ & $\begin{array}{c}-30.6677^{* *} \\
(2.32)\end{array}$ & $\begin{array}{c}-28.4024 * * \\
(2.08)\end{array}$ & $\begin{array}{c}-54.8714^{* *} \\
(3.67)\end{array}$ \\
\hline $\begin{array}{l}\text { Percent Black } \\
\text { (in 1920) }\end{array}$ & & & $\begin{array}{c}-55.3037 * * \\
\quad(3.65)\end{array}$ & $\begin{array}{r}-13.1901 \\
(0.71)\end{array}$ & $\begin{array}{r}-12.9234 \\
(0.69)\end{array}$ & $\begin{array}{c}-37.8683 \text { * } \\
(1.74)\end{array}$ \\
\hline West Dummy & & & $\begin{array}{c}17.2578 \text { ** } \\
(3.49)\end{array}$ & $\begin{array}{c}21.8742 \text { ** } \\
(4.67)\end{array}$ & $\begin{array}{c}21.1836 \text { ** } \\
(4.41)\end{array}$ & \\
\hline $\begin{array}{l}\text { Gini of farm size } \\
\text { (in 1880) }\end{array}$ & & & & $\begin{array}{c}-58.5236 \text { ** } \\
(3.30)\end{array}$ & $\begin{array}{l}-74.0453 \text { ** } \\
(2.68)\end{array}$ & $\begin{array}{c}-68.2059 \text { ** } \\
(2.03)\end{array}$ \\
\hline $\begin{array}{l}\text { Value per farm } \\
\text { (in 1880) }\end{array}$ & & & & $\begin{array}{r}-0.0004 \\
(0.25)\end{array}$ & $\begin{array}{r}-0.0040 \\
(0.78)\end{array}$ & $\begin{array}{r}-0.0088 \\
(1.46)\end{array}$ \\
\hline $\begin{array}{l}\text { Value } \times \text { Gini } \\
\text { (in 1880) }\end{array}$ & & & & & $\begin{array}{r}0.0077 \\
(0.74)\end{array}$ & $\begin{array}{r}0.0165 \\
(1.34)\end{array}$ \\
\hline Constant & $\begin{array}{r}-4.7883 \\
(0.58)\end{array}$ & $\begin{array}{r}-8.9532 \\
(1.28)\end{array}$ & $\begin{array}{c}22.0132 \text { ** } \\
(2.52)\end{array}$ & $\begin{array}{c}34.8223 \text { ** } \\
(3.76)\end{array}$ & $\begin{array}{c}42.7961 \text { ** } \\
(3.00)\end{array}$ & $\begin{array}{c}43.2102 \text { ** } \\
(2.48)\end{array}$ \\
\hline Adj R-squared & 0.4269 & 0.5941 & 0.7561 & 0.8024 & 0.8000 & 0.7031 \\
\hline total observations & 45 & 45 & 45 & 45 & 45 & 45 \\
\hline Method & OLS & OLS & OLS & OLS & OLS & OLS \\
\hline
\end{tabular}

Absolute values of t-ratios are given in parentheses

** indicates significance at $5 \%$

* indicates significance of $10 \%$ 


\section{Table 4 - 1950}

\begin{tabular}{|c|c|c|c|c|c|c|}
\hline Exp Variable & $\begin{array}{c}(1) \\
\text { Exp/Child } \\
\text { in } 1950\end{array}$ & $\begin{array}{c}(2) \\
\text { Exp/Child } \\
\text { in } 1950\end{array}$ & $\begin{array}{c}(3) \\
\text { Exp/Child } \\
\text { in } 1950\end{array}$ & $\begin{array}{c}(4) \\
\text { Exp/Child } \\
\text { in } 1950\end{array}$ & $\begin{array}{c}(5) \\
\text { Exp/Child } \\
\text { in } 1950\end{array}$ & $\begin{array}{c}(6) \\
\text { Exp/Child } \\
\text { in } 1950\end{array}$ \\
\hline $\begin{array}{l}\text { Income per capita } \\
\text { (in 1950) }\end{array}$ & $\begin{array}{c}0.1383^{\text {** }} \\
(8.68)\end{array}$ & $\begin{array}{c}0.1656^{* *} \\
(7.60)\end{array}$ & $\begin{array}{c}0.1302^{\text {** }} \\
(6.87)\end{array}$ & $\begin{array}{c}0.1194^{\text {** }} \\
(5.29)\end{array}$ & $\begin{array}{c}0.1236^{* *} \\
(5.48)\end{array}$ & $\begin{array}{c}0.1582 \text { ** } \\
(6.05)\end{array}$ \\
\hline $\begin{array}{l}\text { Percent Urban } \\
\text { (in 1950) }\end{array}$ & & $\begin{array}{c}-50.8679 * \\
(1.79)\end{array}$ & $\begin{array}{r}-2.7542 \\
(0.12)\end{array}$ & $\begin{array}{r}-15.0726 \\
(0.61)\end{array}$ & $\begin{array}{r}-9.9397 \\
(0.40)\end{array}$ & $\begin{array}{c}-53.8111 * \\
(1.92)\end{array}$ \\
\hline $\begin{array}{l}\text { Percent Black } \\
\text { (in 1950) }\end{array}$ & & & $\begin{array}{r}25.8008 \\
(0.97)\end{array}$ & $\begin{array}{r}16.4902 \\
(0.48)\end{array}$ & $\begin{array}{r}24.9224 \\
(0.73)\end{array}$ & $\begin{array}{r}-48.8358 \\
(1.31)\end{array}$ \\
\hline West Dummy & & & $\begin{array}{c}37.6302 \text { ** } \\
(6.09)\end{array}$ & $\begin{array}{c}36.0743 \text { ** } \\
(5.00)\end{array}$ & $\begin{array}{c}33.5774 \text { ** } \\
(4.55)\end{array}$ & \\
\hline $\begin{array}{l}\text { Gini of farm size } \\
\text { (in 1880) }\end{array}$ & & & & $\begin{array}{r}11.1579 \\
(0.39)\end{array}$ & $\begin{array}{r}-37.1389 \\
(0.81)\end{array}$ & $\begin{array}{r}-13.2087 \\
(0.24)\end{array}$ \\
\hline $\begin{array}{l}\text { Value per farm } \\
\text { (in 1880) }\end{array}$ & & & & $\begin{array}{r}0.0031 \\
(1.32)\end{array}$ & $\begin{array}{r}-0.0078 \\
(0.93)\end{array}$ & $\begin{array}{c}-0.0174 \text { * } \\
(1.74)\end{array}$ \\
\hline $\begin{array}{l}\text { Value } x \text { Gini } \\
\text { (in 1880) }\end{array}$ & & & & & $\begin{array}{r}0.0224 \\
(1.35)\end{array}$ & $\begin{array}{l}0.0415 \text { ** } \\
(2.09)\end{array}$ \\
\hline Constant & $\begin{array}{r}0.3783 \\
(0.03)\end{array}$ & $\begin{array}{r}3.9067 \\
(0.29)\end{array}$ & $\begin{array}{r}-2.9764 \\
(0.21)\end{array}$ & $\begin{array}{r}1.2903 \\
(0.07)\end{array}$ & $\begin{array}{r}19.9228 \\
(0.87)\end{array}$ & $\begin{array}{r}24.2772 \\
(0.86)\end{array}$ \\
\hline Adj R-squared & 0.6281 & 0.6463 & 0.8102 & 0.8102 & 0.8142 & 0.7178 \\
\hline total observations & 45 & 45 & 45 & 45 & 45 & 45 \\
\hline Method & OLS & OLS & OLS & OLS & OLS & OLS \\
\hline
\end{tabular}

Absolute values of t-ratios are given in parentheses

** indicates significance at $5 \%$

* indicates significance of $10 \%$ 